\title{
Dramatic Rise of Seroprevalence Rates of SARS-CoV-2 \\ Antibodies among Healthy Blood Donors: The evolution of a
}

\section{Pandemic}

Maher A. Sughayer ${ }^{a}$ MD, Asem Mansour ${ }^{b}$ MD, Abeer Al Nuirat ${ }^{a}$ MSc, Lina Souan ${ }^{a}$ PhD, Mohammad Ghanem ${ }^{\text {a } M S c, ~ M a h m o u d ~ S i a g ~}{ }^{\mathrm{a}}$ BSc, Sallam Alhassoon ${ }^{\mathrm{a}}$ MSc.

${ }^{a}$ Department of Pathology and Laboratory Medicine, King Hussein Cancer Center, Amman,

Jordan

${ }^{\mathrm{b}}$ Department of Radiology, and CEO, King Hussein Cancer Center

Corresponding Author: Maher A. Sughayer MD,

Msughayer@KHCC.jo

202 Q. Rania St. Amman, 11941, Jordan 
medRxiv preprint doi: https://doi.org/10.1101/2021.03.02.21252448; this version posted March 5, 2021. The copyright holder for this preprint (which was not certified by peer review) is the author/funder, who has granted medRxiv a license to display the preprint in perpetuity.

It is made available under a CC-BY-NC-ND 4.0 International license .

\begin{abstract}
Background: The coronavirus disease 2019 (COVID-19) pandemic has resulted in more than 106 million cases of confirmed infection and more than 2.3 million deaths worldwide as of February 11th 2021. Seroprevalence studies are extremely useful in studying and assessing the epidemiological status in the community and the degree of spread. They help decision makers in implementing or relaxing mitigating measures to contain the disease in addition to other benefits.
\end{abstract}

Objective: To study the seroprevalence rates of SARS-CoV-2 antibodies among healthy blood donors in Jordan, at various points of time as the pandemic evolves in the community.

Methods: A total of 1374 blood donor were tested for the SARS-CoV-2 antibodies in 3 groups.

The first group of 746 and the second of 348 individuals were tested in June and September of 2020 respectively. The $3^{\text {rd }}$ group of 292 were tested in early February of 2021 . We utilized a qualitative assay that uses Electrochemiluminescence method (ECLIA) that has a specificity and sensitivity of $99.8 \%$ and $100 \%$ respectively.

Results: The first 2 groups representing the months of January to September of 2020, where the number of confirmed Covid-19 cases were several hundred to 3000 showed a seroprevalence rate of $0 \%(95 \% \mathrm{Cl} 0.00 \%, 0.51 \%)$. The $3^{\text {rd }}$ group representing late January and early February 2021 when the number of reported confirmed case has reached 100 folds the numbers of September 2020, showed a seroprevalence of $27.4 \%$ (95\% Cl $22.5 \%$ and $32.9 \%)$.

Conclusions: a dramatic rise in seroprevalence of SARS-CoV-2 antibodies was seen among healthy blood donors in Jordan in parallel with wide-spread intracommunity transmission of the disease. This information is useful to assess the degree of herd immunity and provides for better understanding of the pandemic. 
medRxiv preprint doi: https://doi.org/10.1101/2021.03.02.21252448; this version posted March 5, 2021. The copyright holder for this preprint (which was not certified by peer review) is the author/funder, who has granted medRxiv a license to display the preprint in perpetuity.

\section{Introduction}

The coronavirus disease 2019 (COVID-19) pandemic has resulted in more than 106 million cases of confirmed infection and more than 2.3 million deaths worldwide as of February 11th 2021 (European Centre for Disease Prevention and Control, 2021).

Population based Seroprevalence studies are extremely important to understand the evolution of the pandemic and to estimate infection rates and prevalence. They are important for calculating absolute risks of the infection as well as death rates and to predict the spread of the virus in communities based on the level of herd immunity after infections and or vaccination. They are also important for planning and monitoring the impact of implementation and relaxation of epidemic mitigation policies (Busch and Stone, 2021)

The true prevalence of the infection is believed to be several times more than the number of PCR confirmed cases because of the large number of asymptomatic infections and or mild infections that went untested especially early in the pandemic (Huang et al., 2020, McLaughlin et al., 2020, Busch and Stone, 2021. The ratio of estimated to reported infections can range up 12.5 (Bajema et al., 2020)

Numerous population seroprevalence studies were conducted (Bajema et al., 2020, Lai et al., 2020, Chughtai et al., 2020, McLaughlin et al., 2020, Naranbhai et al., 2020, Sam et al., 2021, Sutton et al., 2020, Menachemi et al., 2020, Silveira et al., 2020, Kar et al., 2021, Vena et al., 2020 ,Pollán et al., 2020, Bogogiannidou et al., 2020, Poustchi et al., 2020., Shields et al., 2020, Ng et al., 2020, Figueiredo-Campos et al., 2020, Stringhini et al., 2020, Havers et al., 2020, Ho et al., 2020, Xu et al., 2020, Qutob et al., 2020, Capai et al., 2020 ,Sood et al., 2020, Godbout et al., 2020, Rostami et al., 2020) in efforts to estimate the true prevalence of the COVID-19 infection. 
medRxiv preprint doi: https://doi.org/10.1101/2021.03.02.21252448; this version posted March 5, 2021. The copyright holder for this preprint (which was not certified by peer review) is the author/funder, who has granted medRxiv a license to display the preprint in perpetuity.

It is made available under a CC-BY-NC-ND 4.0 International license .

The largest seroprevalence study was the one by Bajema et al. from the USA which showed by September 2020 that the estimated population seroprevalence to be less than $10 \%$ in the majority of tested communities, although it ranged from 0 up to $23.3 \%$ in the highest hit areas. Obviously the wide variation reflects the level of transmission in the tested communities and number of PCR confirmed reported cases. (Bajema et al., 2020).

Those population- based seroprevalence studies varied in the targeted populations tested and the recruitment strategies used which may explain some of the variation. Among the populations tested are healthy blood donors (Sughayer et al., 2020, Slot et al., 2020, Daniel J. Nesbitt et al., 2021, Gallian et al., 2020, Olariu et al., 2021, Younas et al., 2020, Banjar et al., 2021, Uyoga et al., 2021, Busch and Stone, 2021, Martinez-Acuña et al., 2020, Saeed et al., 2021, Slot et al., 2020, Fiore et al., 2021). Again the seroprevalence among healthy blood donors and other population groups studied varied according to the community tested and the time of testing in terms of the pandemic evolution (Lai et al., 2020, Rostami et al., 2020)

In this longitudinal study we aimed to estimate the seroprevalence of Covid-19 among healthy blood donors in Jordan at different points in time to assess the degree of community spread and herd immunity and to further understand the evolution of the pandemic. This is the first longitudinal seroprevalence study in blood donors and the first from Jordan.

\section{Methods:}

\section{Subjects and samples:}

Left over sera and or plasma collected routinely during the process of blood or apheresis platelet donations were used for the study. The donors were healthy asymptomatic subjects between the ages of 18 and 63 who underwent routine screening to determine their 
medRxiv preprint doi: https://doi.org/10.1101/2021.03.02.21252448; this version posted March 5, 2021. The copyright holder for this preprint (which was not certified by peer review) is the author/funder, who has granted medRxiv a license to display the preprint in perpetuity.

It is made available under a CC-BY-NC-ND 4.0 International license .

acceptability for donation as per standard practice. The sera were tested in 3 batches at 3 different times. The first batch consisting of 746 samples representing the period of January to June 2020 was tested in June of that year. The second batch of 348 samples were collected and tested in September of 2020 while the third batch of 292 samples were collected during the period of January 28-Februay 5, 2021 and tested in the same period. Thus the total number of donors tested in the study was 1374 .

\section{Testing Methodology:}

The samples were tested according to the manufactures recommendations using a commercially available FDA approved kit for total immunoglobulins against SARS-Cov-2. The test was performed on Cobas 6000 or Cobas Pro, Roche analyzers , using the Elecsys-AntiSARS-CoV-2 kit (Roche Diagnostics GmbH, Mannheim). This test is a qualitative assay that uses Electrochemiluminescence Method (ECLIA) which is an immunoassay for the in vitro qualitative detection of antibodies (including IgG) to SARS-CoV-2 in human serum and plasma. The assay uses a recombinant protein representing the nucleocapsid $(\mathrm{N})$ antigen for the determination of antibodies against SARS-CoV-2. The test was validated by the manufacturer using 5272 samples including blood donors, diagnostic routine, other corona viruses and common cold panels. The specificity was determined to be $99.8 \%(95 \% \mathrm{Cl}, 99.7 \%-99.9 \%)$. while the sensitivity was $100 \%(95 \% \mathrm{Cl}, 88.3 \%-100.0 \%)$.

In house validation using serum samples obtained from previously RT-PCR- confirmed Covid19 infected patients who have recovered at least one month prior to sampling was performed.

\section{Statistics:}

Descriptive statistics were used to analyze the results. Chi square statistics were used to compare the seropositive donors' characteristics versus the seronegative ones. We adjusted 
medRxiv preprint doi: https://doi.org/10.1101/2021.03.02.21252448; this version posted March 5, 2021. The copyright holder for this preprint (which was not certified by peer review) is the author/funder, who has granted medRxiv a license to display the preprint in perpetuity.

It is made available under a CC-BY-NC-ND 4.0 International license .

the estimated prevalence to test's sensitivity and specificity using an online tool:

http://www2.univet.hu/users/jreiczig/Cl4prevSeSp/calc02/index.php as. per methods described by Lang and Reiczjkl (Lang and Reiczigel, 2014).

Ethical approval:

All necessary approvals were obtained.

\section{Results:}

The demographics of the donors and the period of donation are summarized in table 1 . The donors were mostly males (86\%) and from the capitol city of Amman, Jordan (78\%).

The first group was previously reported in a preprint (Sughayer et al., 2020) and revealed along with the second group a seroprevalence rate of $0 \%$ in each group $(95 \% \mathrm{Cl} \quad 0.00 \%, 0.51 \%)$.

The third group on the other hand which represents the most recent period of January 28-

February 5, 2021, showed a positive serological test for the SARS CoV-2 in 80 of 292 donors; a crude seroprevalence rate of $27.4 \%$. The adjusted estimated seroprevalence rate is $27.3 \%$ (95\% confidence intervals $22.5 \%$ and $32.9 \%$ ) The demographics and characteristics of the seropositive donors in comparison to the seronegative ones are shown in Table 2. Most of those who tested positive (85\%) were in the age group of $18-40$ years. However there was no statistically significant difference between the seropositive and negative donors in terms of gender, age, blood group or residence. Males and females were almost equally affected (27.6\% vs $26.3 \%)$.

One fifth of the seropositive donors were retrospectively found to have been confirmed positive for the covid-19 infection by the PCR test. Forty seven (58.8\%) were not known to have the 
medRxiv preprint doi: https://doi.org/10.1101/2021.03.02.21252448; this version posted March 5, 2021. The copyright holder for this preprint (which was not certified by peer review) is the author/funder, who has granted medRxiv a license to display the preprint in perpetuity.

It is made available under a CC-BY-NC-ND 4.0 International license.

disease and so did not undergo or underwent a PCR test with negative result. There was no information with regards to previous infection for 17 of the seropositive donors.

\section{Discussion:}

The importance of serological testing for the SARS COV-2 antibodies have been previously highlighted (Busch and Stone, 2021, Raoult, 2021). Among the advantages of such testing is the understanding of the evolution of the pandemic in terms of having a rough estimation of the prevalence of the infection. This will serve health planners and decision makers to properly enforce or relax mitigation measures. And most importantly at these times as vaccines are being rolled out it serves in estimating the risk rates for the infection, the degree of herd immunity and helps prioritizing vaccine recipients. .

In this study we measured the seroprevalence rates in healthy blood donors at three points in time. The results are striking in that they show a dramatic change from $0 \%$ early and in the middle of the pandemic, up to $27.4 \%$ in February of 2021 . These findings would be reasonable if we consider the cumulative number of confirmed cases around these times in Jordan. Figure 1 shows the cumulative daily cases of Covid-19 in Jordan. In the first period up till June 2020 there were only several hundred confirmed cases which increased gradually to around 3000 cases in early September (WHO, 2021). However towards the end of September and afterwards the cumulative number of cases started a steep rise so that on Februay 5, 2021 the cumulative number of confirmed cases was more than 100 folds that of September 2020. It is worth mentioning that a strict lockdown was in effect till early June that was gradually relaxed over three months with full opening of all sectors including schools and international travel in September 2020. It is clear that the first wave of the Covid-19 pandemic in Jordan has actually started in late September when the community was fully open and the intracommunity spread 
medRxiv preprint doi: https://doi.org/10.1101/2021.03.02.21252448; this version posted March 5, 2021. The copyright holder for this preprint (which was not certified by peer review) is the author/funder, who has granted medRxiv a license to display the preprint in perpetuity.

It is made available under a CC-BY-NC-ND 4.0 International license .

became evident. Before that the several hundred cases were actually limited to transmission within known specific hot foci. This explains the extremely low seroprevalence initially found in June and September of last year, as the infection transmission was under strict control with quarantine routinely imposed on all contacts of index cases.

The current (early February 2021) crude seroprevalence rate of $27.4 \%$, if can be generalized to the population at large would mean that the number of cases is roughly 2.7 million in a population of 10 million in Jordan. This, if true, means that there are 8 cases for every confirmed case. This high ratio of estimated to reported cases is similar to some of the highest ratios reported by Bajema et al. in the USA (Bajema et al., 2020). Looking at it from a different angle we can also see that in our rather small sample one fifth of the donors were previously confirmed positive by the PCR test so we may assume a ratio of estimated to reported cases to be 5 at the lowest estimate.

Most of our seropositive donors (85\%) were young; below 40 years of age. This finding helps in setting the vaccination priority for those older than 40 years. Other studies have shown inconsistent findings with either similar age group distribution to our cohort or the opposite with higher rate in older individuals (Bajema et al., 2020 ,Martinez-Acuña et al., 2020, Vena et al., 2020, Olariu et al., 2021).

Our findings are also in line with previous studies which showed that early in the pandemic the seroprevalence of Covid-19 in blood donors or other nontargeted populations was very low ranging from 0\% to 2.0\% (Erikstrup et al., 2021, Godbout et al., 2020, Qutob et al., 2020, Xu et al., 2020, Ho et al., 2020, Banjar et al., 2021, Nesbitt et al., 2021Slot et al., 2020, Fiore et al., 2021, Saeed et al., 2021). However other studies especially those from hardly hit communities early in the pandemic showed relatively high rates up to $23 \%$ (Percivalle et al., 2020). 
medRxiv preprint doi: https://doi.org/10.1101/2021.03.02.21252448; this version posted March 5, 2021. The copyright holder for this preprint (which was not certified by peer review) is the author/funder, who has granted medRxiv a license to display the preprint in perpetuity.

It is made available under a CC-BY-NC-ND 4.0 International license.

Our current high seroprevalence rate (as of early February 2021) is similar to that of communities that were hardly affected by the pandemic such as that of New York City and Chelsea, Massachusetts (Bajema et al., 2020, Naranbhai et al., 2020).

With regards to blood group association with decreased risk for Covid-19 infection in blood group O (Gallian et al., 2020) our limited data did not reveal such an association.

Our study to our knowledge is the first longitudinal study of covid-19 seroprevalence in healthy blood donors.

There are some limitations in our study including the small number of the blood donors in the 3rd group. In addition the blood donors are mostly males and of younger age groups. However the age groups represented in our study constitute around $60 \%$ of the Jordanian population, the rest being mostly children under the age of 18 . Thus it may be difficult to draw generalization as there may be selection bias and nonrepresentation of the entire population. Further studies are recommended to include children and the elderly. 
medRxiv preprint doi: https://doi.org/10.1101/2021.03.02.21252448; this version posted March 5, 2021. The copyright holder for this preprint

(which was not certified by peer review) is the author/funder, who has granted medRxiv a license to display the preprint in perpetuity.

It is made available under a CC-BY-NC-ND 4.0 International license .

\section{References:}

Amorim Filho, L., Szwarcwald, C.L., Mateos, S. de O.G., Leon, A.C.M.P. de, Medronho, R. de A., Veloso, V.G., Lopes, J.I.F., Porto, L.C. de M.S., Chieppe, A., Werneck, G.L., 2020.

Seroprevalence of anti-SARS-CoV-2 among blood donors in Rio de Janeiro, Brazil. Revista de saude publica $54,69$.

Bajema, K.L., Wiegand, R.E., Cuffe, K., Patel, S.V., Iachan, R., Lim, T., Lee, A., Moyse, D., Havers, F.P., Harding, L., Fry, A.M., Hall, A.J., Martin, K., Biel, M., Deng, Y., Meyer, W.A., III, Mathur, M., Kyle, T., Gundlapalli, A.V., Thornburg, N.J., Petersen, L.R., Edens, C., 2020. Estimated SARS-CoV-2 Seroprevalence in the US as of September 2020. JAMA Internal Medicine. https://doi.org/10.1001/jamainternmed.2020.7976

Banjar, A., Al-Tawfiq, J.A., Alruwaily, A., Alserehi, H., Al-Qunaibet, A., Alaswad, R., Almutlaq, H., Almudaiheem, A., Khojah, A.T., Alsaif, F., Almolad, S.K., Alqahtani, S., AlJurayyan, A., Alotaibi, A., Almalki, S., Abuhaimed, Y., Alkhashan, A., Alfaifi, A., Alabdulkareem, K., Jokhdar, H., Assiri, A., Almudarra, S., 2021. Seroprevalence of antibodies to SARS-CoV-2 among blood donors in the early months of the pandemic in Saudi Arabia. International Journal of Infectious Diseases 104, 452-457. https://doi.org/10.1016/j.ijid.2021.01.028

Bogogiannidou, Z., Vontas, A., Dadouli, K., Kyritsi, M.A., Soteriades, S., Nikoulis, D.J., Mouchtouri, V.A., Koureas, M., Kazakos, E.I., Spanos, E.G., 2020. Repeated leftover serosurvey of SARS-

CoV-2 IgG antibodies, Greece, March and April 2020. Eurosurveillance 25, 2001369.

Busch, M.P., Stone, M., 2021. Serosurveillance for Severe Acute Respiratory Syndrome Coronavirus 2 (SARS-CoV-2) Incidence Using Global Blood Donor Populations. Clinical Infectious Diseases 72, 254-256. https://doi.org/10.1093/cid/ciaa1116

Capai, L., Ayhan, N., Masse, S., Canarelli, J., Priet, S., Simeoni, M.-H., Charrel, R., de Lamballerie, X., Falchi, A., 2020. Seroprevalence of SARS-CoV-2 IgG Antibodies in Corsica (France), April and June 2020. Journal of Clinical Medicine 9. https://doi.org/10.3390/jcm9113569

Chughtai, O.R., Batool, H., Khan, M.D., Chughtai, A.S., 2020. Frequency of COVID-19 IgG Antibodies among Special Police Squad Lahore, Pakistan. J Coll Physicians Surg Pak 30, 735739. https://doi.org/10.29271/jcpsp.2020.07.735

Daniel J. Nesbitt, Daniel P. Jin, Joseph W. Hogan, Philip A Chan, Melissa J Simon, Matthew Vargas, Ewa King, Richard C Huard, Utpala Bandy, Christopher Hillyer, Larry Luchsinger, 2021. Low Seroprevalence of SARS-CoV-2 in Rhode Island Blood Donors Determined Using Multiple Serological Assay Formats. BMC Infectious Diseases. https://doi.org/10.21203/rs.3.rs-76664/v1

Erikstrup, C., Hother, C.E., Pedersen, O.B.V., Mølbak, K., Skov, R.L., Holm, D.K., Sækmose, S.G., Nilsson, A.C., Brooks, P.T., Boldsen, J.K., 2021. Estimation of SARS-CoV-2 infection fatality rate by real-time antibody screening of blood donors. Clinical Infectious Diseases 72, 249-253.

European Centre for Disease Prevention and Control, Covid-19,

https://www.ecdc.europa.eu/en/geographical-distribution-2019-ncov-cases, Accessed on February 11, 2021)

Figueiredo-Campos, P., Blankenhaus, B., Mota, C., Gomes, A., Serrano, M., Ariotti, S., Costa, C., Nunes-Cabaço, H., Mendes, A.M., Gaspar, P., Pereira-Santos, M.C., Rodrigues, F., Condeço, J., Escoval, M.A., Santos, M., Ramirez, M., Melo-Cristino, J., Simas, J.P., Vasconcelos, E., Afonso, Â., Veldhoen, M., 2020. Seroprevalence of anti-SARS-CoV-2 antibodies in COVID-19 patients and healthy volunteers up to 6 months post disease onset. European Journal of Immunology 50, 2025-2040. https://doi.org/10.1002/eji.202048970 
medRxiv preprint doi: https://doi.org/10.1101/2021.03.02.21252448; this version posted March 5, 2021. The copyright holder for this preprint (which was not certified by peer review) is the author/funder, who has granted medRxiv a license to display the preprint in perpetuity. It is made available under a CC-BY-NC-ND 4.0 International license .

Fiore, J.R., Centra, M., De Carlo, A., Granato, T., Rosa, A., Sarno, M., De Feo, L., Di Stefano, M., Errico, M.D., Caputo, S.L., 2021. Results from a survey in healthy blood donors in South Eastern Italy indicate that we are far away from herd immunity to SARS $\square \operatorname{CoV} \square 2$. Journal of Medical Virology 93, 1739-1742.

Gallian, P., Pastorino, B., Morel, P., Chiaroni, J., Ninove, L., de Lamballerie, X., 2020. Lower prevalence of antibodies neutralizing SARS-CoV-2 in group O French blood donors. Antiviral research 181, 104880.

Godbout, E.J., Pryor, R., Harmon, M., Montpetit, A., Greer, J., Bachmann, L.M., Doll, M., Stevens, M.P., Bearman, G., 2020. Severe acute respiratory coronavirus virus 2 (SARS-CoV-2) seroprevalence among healthcare workers in a low prevalence region. Infection Control \& Hospital Epidemiology 1-3. https://doi.org/10.1017/ice.2020.1374

Havers, F.P., Reed, C., Lim, T., Montgomery, J.M., Klena, J.D., Hall, A.J., Fry, A.M., Cannon, D.L., Chiang, C.-F., Gibbons, A., 2020. Seroprevalence of antibodies to SARS-CoV-2 in 10 sites in the United States, March 23-May 12, 2020. JAMA internal medicine 180, 1576-1586.

Ho, H.-L., Wang, F.-Y., Lee, H.-R., Huang, Y.-L., Lai, C.-L., Jen, W.-C., Hsieh, S.-L., Chou, T.-Y., 2020. Seroprevalence of COVID-19 in Taiwan revealed by testing anti-SARS-CoV-2 serological antibodies on 14,765 hospital patients. The Lancet Regional Health - Western Pacific 3, 100041. https://doi.org/10.1016/j.lanwpc.2020.100041

Huang, L., Zhang, Xiuwen, Zhang, Xinyue, Wei, Z., Zhang, L., Xu, J., Liang, P., Xu, Y., Zhang, C., $\mathrm{Xu}$, A., 2020. Rapid asymptomatic transmission of COVID-19 during the incubation period demonstrating strong infectivity in a cluster of youngsters aged 16-23 years outside Wuhan and characteristics of young patients with COVID-19: A prospective contact-tracing study. Journal of Infection 80, e1-e13. https://doi.org/10.1016/j.jinf.2020.03.006

Kar, S.S., Sarkar, S., Murali, S., Dhodapkar, R., Joseph, N.M., Aggarwal, R., 2021. Prevalence and Time Trend of SARS-CoV-2 Infection in Puducherry, India, August-October 2020. Emerging Infectious Disease journal 27, 666. https://doi.org/10.3201/eid2702.204480

Lai, C.-C., Wang, J.-H., Hsueh, P.-R., 2020. Population-based seroprevalence surveys of anti-SARSCoV-2 antibody: An up-to-date review. International Journal of Infectious Diseases 101, 314 322. https://doi.org/10.1016/j.ijid.2020.10.011

Lang, Z., Reiczigel, J., 2014. Confidence limits for prevalence of disease adjusted for estimated sensitivity and specificity. Prev Vet Med 113, 13-22. https://doi.org/10.1016/j.prevetmed.2013.09.015

Martinez-Acuña, N., Avalos-Nolazco, D., Rodriguez-Rodriguez, D., Martinez-Liu, C., Taméz, R.C., Flores-Arechiga, A. 2020. Seroprevalence of anti-SARS-COV-2 antibodies in blood donors from Nuevo Leon state, Mexico, during the beginning of the COVID-19 pandemic. medRxiv 2020.11.28.20240325. https://doi.org/10.1101/2020.11.28.20240325

McLaughlin, C.C., Doll, M.K., Morrison, K.T., McLaughlin, W.L., O’Connor, T., Sholukh, A.M., Bossard, E.L., Phasouk, K., Ford, E.S., Diem, K., 2020. High community SARS-CoV-2 antibody seroprevalence in a ski resort community, Blaine County, Idaho, US. preliminary results. Medrxiv.

Menachemi, N., Yiannoutsos, C.T., Dixon, B.E., Duszynski, T.J., Fadel, W.F., Wools-Kaloustian, K.K., Needleman, N.U., Box, K., Caine, V., Norwood, C., 2020. Population point prevalence of SARS-CoV-2 infection based on a statewide random sample-Indiana, April 25-29, 2020. Morbidity and Mortality Weekly Report 69, 960. 
medRxiv preprint doi: https://doi.org/10.1101/2021.03.02.21252448; this version posted March 5, 2021. The copyright holder for this preprint (which was not certified by peer review) is the author/funder, who has granted medRxiv a license to display the preprint in perpetuity. It is made available under a CC-BY-NC-ND 4.0 International license .

Naranbhai, V., Chang, C.C., Beltran, W.F.G., Miller, T.E., Astudillo, M.G., Villalba, J.A., Yang, D., Gelfand, J., Bernstein, B.E., Feldman, J., 2020. High seroprevalence of anti-SARS-CoV-2 antibodies in Chelsea, Massachusetts. The Journal of infectious diseases 222, 1955-1959.

Ng, D.L., Goldgof, G.M., Shy, B.R., Levine, A.G., Balcerek, J., Bapat, S.P., Prostko, J., Rodgers, M., Coller, K., Pearce, S., 2020. SARS-CoV-2 seroprevalence and neutralizing activity in donor and patient blood. Nature communications 11, 1-7.

Olariu, T.R., Lighezan, R., Ursoniu, S., Craciun, A.C., Paduraru, A.A., Lupu, M.A., n.d. Seroprevalence of SARS-CoV-2 antibodies in 2115 blood donors from Romania. Clinical Microbiology and Infection. https://doi.org/10.1016/j.cmi.2020.12.027

Percivalle, E., Cambiè, G., Cassaniti, I., Nepita, E.V., Maserati, R., Ferrari, A., Di Martino, R., Isernia, P., Mojoli, F., Bruno, R., 2020. Prevalence of SARS-CoV-2 specific neutralising antibodies in blood donors from the Lodi Red Zone in Lombardy, Italy, as at 06 April 2020. Eurosurveillance 25, 2001031.

Pollán, M., Pérez-Gómez, B., Pastor-Barriuso, R., Oteo, J., Hernán, M.A., Pérez-Olmeda, M. 2020. Prevalence of SARS-CoV-2 in Spain (ENE-COVID): a nationwide, population-based seroepidemiological study. The Lancet 396, 535-544. https://doi.org/10.1016/S0140$\underline{6736(20) 31483-5}$

Poustchi, H., Darvishian, M., Mohammadi, Z., Shayanrad, A., Delavari, A., Bahadorimonfared, A. SARS-CoV-2 antibody seroprevalence in the general population and high-risk occupational groups across 18 cities in Iran: a population-based cross-sectional study. The Lancet Infectious Diseases. https://doi.org/10.1016/S1473-3099(20)30858-6

Qutob, N., Awartani, F., Salah, Z., Asia, M., Khader, I.A., Herzallah, K., Balqis, N., Sallam, H., n.d. Seroprevalence of SARS-CoV-2 in the West Bank region of Palestine: a cross- sectional seroepidemiological study. Open access 5.

Raoult, D., 2021. How useful is serology for COVID-19? International Journal of Infectious Diseases 102, 170-171. https://doi.org/10.1016/j.ijid.2020.10.058

Rosenberg, E.S., Tesoriero, J.M., Rosenthal, E.M., Chung, R., Barranco, M.A., Styer, L.M., Parker, M.M., Leung, S.-Y.J., Morne, J.E., Greene, D., 2020. Cumulative incidence and diagnosis of SARS-CoV-2 infection in New York. Annals of epidemiology 48, 23-29.

Rostami, A., Sepidarkish, M., Leeflang, M.M.G., Riahi, S.M., Nourollahpour Shiadeh, M., Esfandyari, S., Mokdad, A.H., Hotez, P.J., Gasser, R.B., 2020. SARS-CoV-2 seroprevalence worldwide: a systematic review and meta-analysis. Clin Microbiol Infect S1198743X(20)30651-0. https://doi.org/10.1016/j.cmi.2020.10.020

Saeed, S., Drews, S.J., Pambrun, C., Yi, Q.-L., Osmond, L., O’Brien, S.F., 2021. SARS-CoV-2 seroprevalence among blood donors after the first COVID-19 wave in Canada. Transfusion n/a. https://doi.org/10.1111/trf.16296

Sam, I.-C., Chong, Y.M., Tan, C.W., Chan, Y.F., 2021. Low postpandemic wave SARS-CoV-2 seroprevalence in Kuala Lumpur and Selangor, Malaysia. Journal of Medical Virology 93, 647648. https://doi.org/10.1002/jmv.26426

Silveira, M.F., Barros, A.J., Horta, B.L., Pellanda, L.C., Victora, G.D., Dellagostin, O.A., Struchiner, C.J., Burattini, M.N., Valim, A.R., Berlezi, E.M., 2020. Population-based surveys of antibodies against SARS-CoV-2 in Southern Brazil. Nature Medicine 26, 1196-1199.

Slot, E., Hogema, B.M., Reusken, C.B.E.M., Reimerink, J.H., Molier, M., Karregat, J.H.M., IJlst, J., Novotný, V.M.J., van Lier, R.A.W., Zaaijer, H.L., 2020. Low SARS-CoV-2 seroprevalence in blood donors in the early COVID-19 epidemic in the Netherlands. Nature Communications 11, 5744. https://doi.org/10.1038/s41467-020-19481-7 
medRxiv preprint doi: https://doi.org/10.1101/2021.03.02.21252448; this version posted March 5, 2021. The copyright holder for this preprint (which was not certified by peer review) is the author/funder, who has granted medRxiv a license to display the preprint in perpetuity. It is made available under a CC-BY-NC-ND 4.0 International license .

Sood, N., Simon, P., Ebner, P., Eichner, D., Reynolds, J., Bendavid, E., Bhattacharya, J., 2020. Seroprevalence of SARS-CoV-2-specific antibodies among adults in Los Angeles County, California, on April 10-11, 2020. Jama 323, 2425-2427.

Stringhini, S., Wisniak, A., Piumatti, G., Azman, A.S., Lauer, S.A., Baysson, H., De Ridder, D., Petrovic, D., Schrempft, S., Marcus, K., 2020. Seroprevalence of anti-SARS-CoV-2 IgG antibodies in Geneva, Switzerland (SEROCoV-POP): a population-based study. The Lancet 396, 313-319.

Sughayer, M.A., Mansour, A., Nuirat, A.A., Souan, L., Ghanem, M., Siag, M., 2020. The effect of strict lock down measures on Covid-19 seroprevalence rate and herd immunity. medRxiv 2020.06.06.20123919. https://doi.org/10.1101/2020.06.06.20123919

Sutton, M., Cieslak, P., Linder, M., 2020. Notes from the Field: Seroprevalence Estimates of SARSCoV-2 Infection in Convenience Sample-Oregon, May 11-June 15, 2020. Morbidity and Mortality Weekly Report 69, 1100.

Uyoga, S., Adetifa, I.M.O., Karanja, H.K., Nyagwange, J., Tuju, J., Wanjiku, P. 2021. Seroprevalence of anti-SARS-CoV-2 IgG antibodies in Kenyan blood donors. Science 371, 79. https://doi.org/10.1126/science.abe1916

Vena, A., Berruti, M., Adessi, A., Blumetti, P., Brignole, M., Colognato, R., Gaggioli, G., Giacobbe, D.R., Bracci-Laudiero, L., Magnasco, L., 2020. Prevalence of antibodies to SARS-CoV-2 in Italian adults and associated risk factors. Journal of clinical medicine 9, 2780.

WHO coronavirus disease (COVID-19) dashboard. Geneva: World Health Organization, 2020. Available online: https://covid19.who.int/ (last cited: February 15, 2021)

Xu, X., Sun, J., Nie, S., Li, H., Kong, Y., Liang, M., Hou, J., Huang, X., Li, D., Ma, T., Peng, J., Gao, S., Shao, Y., Zhu, H., Lau, J.Y.-N., Wang, G., Xie, C., Jiang, L., Huang, A., Yang, Z., Zhang, K., Hou, F.F., 2020. Seroprevalence of immunoglobulin M and G antibodies against SARS-CoV-2 in China. Nature Medicine 26, 1193-1195. https://doi.org/10.1038/s41591-020-0949-6

Younas, A., Waheed, S., Khawaja, S., Imam, M., Borhany, M., Shamsi, T., 2020. Seroprevalence of SARS-CoV-2 antibodies among healthy blood donors in Karachi, Pakistan. Transfusion and Apheresis Science 59. https://doi.org/10.1016/j.transci.2020.102923 
medRxiv preprint doi: https://doi.org/10.1101/2021.03.02.21252448; this version posted March 5, 2021. The copyright holder for this preprint (which was not certified by peer review) is the author/funder, who has granted medRxiv a license to display the preprint in perpetuity.

It is made available under a CC-BY-NC-ND 4.0 International license.

Figure 1

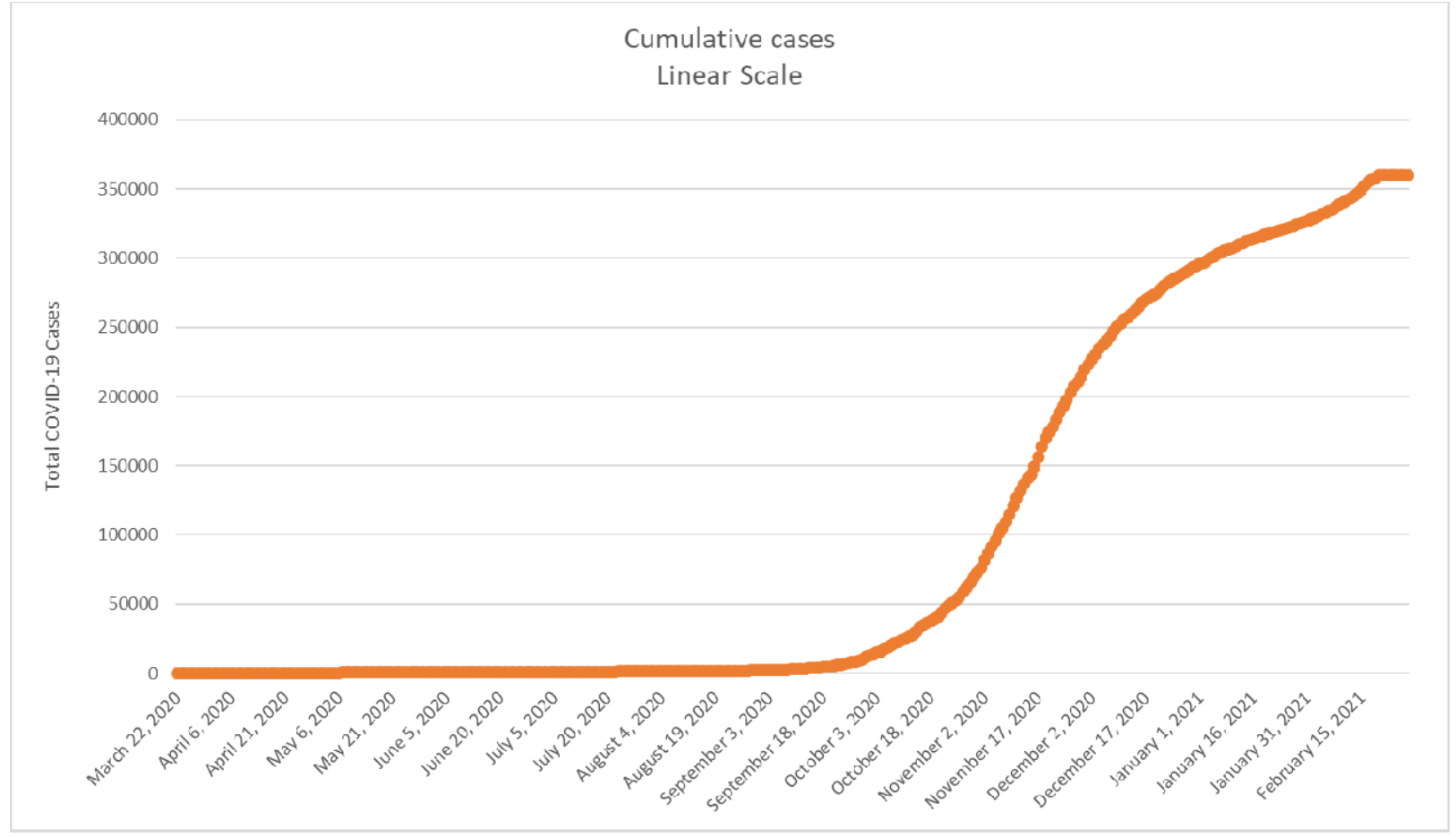


medRxiv preprint doi: https://doi.org/10.1101/2021.03.02.21252448; this version posted March 5, 2021. The copyright holder for this preprint (which was not certified by peer review) is the author/funder, who has granted medRxiv a license to display the preprint in perpetuity. It is made available under a CC-BY-NC-ND 4.0 International license .

\section{Table 1}

\begin{tabular}{|c|c|}
\hline \multicolumn{2}{|c|}{ Demographics of the 1374 Healthy Donors- No. (\%) } \\
\hline Male & $1177(85.7 \%)$ \\
\hline Female & $197(14.3 \%)$ \\
\hline $\begin{array}{l}\text { Residential area: Amman } \\
\text { West Amman }\end{array}$ & $\begin{array}{l}1077(78.4 \%) \\
706(65.6 \%)\end{array}$ \\
\hline East Amman & $371(34.4 \%)$ \\
\hline $\begin{array}{c}\text { District outside Amman } \\
\text { North }\end{array}$ & $\begin{array}{l}297(21.6 \%) \\
128(9.3 \%)\end{array}$ \\
\hline Center & $138(10.1 \%)$ \\
\hline South & $31(2.3 \%)$ \\
\hline \multicolumn{2}{|l|}{ Period } \\
\hline January-2020 & $104(7.6 \%)$ \\
\hline February-2020 & $89(6.5 \%)$ \\
\hline March-2020 & $90(6.6 \%)$ \\
\hline April-2020 & $147(10.7 \%)$ \\
\hline May-2020 & $229(16.7 \%)$ \\
\hline June-2020 & $75(5.4 \%)$ \\
\hline Septemper-2020 & $348(25.3 \%)$ \\
\hline 28 Jan- Feb $5^{\text {th }}, 2021$ & $292(21.3 \%)$ \\
\hline
\end{tabular}


medRxiv preprint doi: https://doi.org/10.1101/2021.03.02.21252448; this version posted March 5, 2021. The copyright holder for this preprint (which was not certified by peer review) is the author/funder, who has granted medRxiv a license to display the preprint in perpetuity.

It is made available under a CC-BY-NC-ND 4.0 International license .

Table 2

Comparison of seronegative and seropositive donors

\begin{tabular}{|c|c|c|c|c|}
\hline Category & $\begin{array}{l}\begin{array}{l}\text { Seropositive } \\
\text { donors }\end{array} \\
80 \text { of } 292\end{array}$ & $\begin{array}{l}\text { Seronegative } \\
\text { donors } \\
212 \text { of } 292\end{array}$ & $p$-value & $\begin{array}{l}\text { Crud } \\
\text { Prevalence } \\
\text { rate }\end{array}$ \\
\hline number of donors & $80(\%)$ & $212(\%)$ & & $27.4 \%$ \\
\hline Male & $70(87.5 \%)$ & $184(86.8 \%)$ & 0.9 & $27.6 \%$ \\
\hline Female & $10(12.5 \%)$ & $28(11.8 \%)$ & & $26.3 \%$ \\
\hline Age (yr) & $47(58.8 \%)$ & $116(54.7 \%)$ & 0.4 & $28.8 \%$ \\
\hline $31-40$ & $21(26.3 \%)$ & $52(24.5 \%)$ & & $28.8 \%$ \\
\hline $41-50$ & $11(13.7 \%)$ & $24(11.3 \%)$ & & $31.4 \%$ \\
\hline $51-65$ & $1(1.2 \%)$ & $11(5.2 \%)$ & & $8.3 \%$ \\
\hline Unknown & 0 & $9(4.2 \%)$ & & \\
\hline Blood group: & $33(41.3 \%)$ & $88(41.5 \%)$ & 0.5 & $27.3 \%$ \\
\hline $\bar{A}$ & $23(28.8 \%)$ & $73(34.4 \%)$ & & $24.0 \%$ \\
\hline B & $15(18.7 \%)$ & 37 (17.5\%) & & $28.8 \%$ \\
\hline$A B$ & $9(11.2 \%)$ & $14(6.6 \%)$ & & $39.1 \%$ \\
\hline Residential Location North & $7(8.8 \%)$ & $33(15.6 \%)$ & 0.3 & $17.5 \%$ \\
\hline Center including Amman & $68(85.0 \%)$ & $168(79.2 \%)$ & & $28.8 \%$ \\
\hline South & $5(6.2 \%)$ & $11(5.2 \%)$ & & $31.3 \%$ \\
\hline PCR-Confirmed past infection & $16(20 \%)$ & 0 & & \\
\hline No/negative PCR & $47(58.8 \%)$ & $180(84.9 \%)$ & & \\
\hline No information available & $17(21.2 \%)$ & $32(15.1 \%)$ & & \\
\hline
\end{tabular}


medRxiv preprint doi: https://doi.org/10.1101/2021.03.02.21252448; this version posted March 5, 2021. The copyright holder for this preprint (which was not certified by peer review) is the author/funder, who has granted medRxiv a license to display the preprint in perpetuity.

\author{
It is made available under a CC-BY-NC-ND 4.0 International license
}

